\title{
POSTPARTUM EDUCATION IN THE WORKING AREA OF THE TEBING COMMUNITY HEALTH CENTER
}

\author{
Nur Zahara Siddik ${ }^{1}$, Ronny Sutanto ${ }^{2}$ \\ nurzaharasiddik@univbatam.ac.id ${ }^{1}$,ronnysutanto@univbatam.ac.id ${ }^{2}$ \\ Medical Education Study Program, Faculty of Medicine, Batam University ${ }^{1}$ \\ Doctor's Professional Study Program, Faculty of Medicine, Batam University ${ }^{2}$ \\ Jl. Uniba No. 5, Batam Center
}

\begin{abstract}
Background : For early detection of complications in postpartum mothers, it is necessary to monitor the examination of postpartum mothers and increase the coverage of postpartum family planning by making at least 3 postpartum visits with time requirements, namely: the first postpartum visit during the period of 6 hours to 3 days after delivery, the second postpartum visit. within the 4th day to the 28th day after delivery, the third postpartum visit within the 29th to 42nd day after delivery. (MOH, 2012). The purpose of this study was to determine the education of postpartum mothers in the Tebing Community Health Center.

Method : This study used a descriptive research design. The research was conducted in the working area of the Tebing Community Health Center. In the study, the population was postpartum mothers who were in the working area of the Tebing Community Health Center. In this study, researchers used purposive sampling technique, which is to determine a sample of the population based on specific objectives or according to the criteria desired by the researcher. The samples taken in this study were postpartum mothers in the working area of the Tebing Community Health Center. The method / technique of data collection was carried out by means of direct communication, namely by asking questions through written questionnaires with postpartum mothers who were in the working area of the Tebing Community Health Center. Univariate analysis is used to explain or describe the characteristics of each variable under study by presenting a description of the frequency distribution.
\end{abstract}

Result : It is known that the majority of respondents' education is low as many as 31 respondents (70.5\%) of 44 respondents

Conclusion : It is known that the majority of respondents' education is low as many as 31 respondents $(70.5 \%)$ of 44 respondents

Keywords: Education, Mother, Postpartum

\section{INTRODUCTION}

The puerperium begins when the baby is born or when the placenta is released and ends when the uterus organs return to their prepregnancy state. The puerperium period (puerperium) lasts for about 6 weeks after delivery, which is a critical period in the mother's life as well as changes, including physical changes, psychological changes, uterine shrinkage and discharge as well as breastfeeding and changes in her body system during pregnancy. The postpartum period is important because it is a critical period for both mother and baby. It is estimated that $60 \%$ of maternal deaths due to pregnancy occur after delivery and $50 \%$ of postpartum deaths occur after the first 24 hours (BKKBN, 2016).

For early detection of complications in postpartum mothers, it is necessary to monitor the examination of postpartum mothers and increase the coverage of postpartum family planning by making at least 3 postpartum visits with time requirements, namely: the first postpartum visit during the period of 6 hours to 
3 days after delivery, the second postpartum visit. within the 4th day to the 28th day after delivery, the third postpartum visit within the 29th to 42nd day after delivery. (MOH, 2012)

The health status of a country is determined by several indicators, one of these indicators is the Maternal Mortality Rate (MMR), the Maternal Mortality Rate according to the Indonesian Health Demographic Survey (IDHS, 2007) is 228 per 100,000 live births, while the MDGs target in 2015, MMR can be reduced to 102 per 100,000 live births $(\mathrm{MOH}$, 2011). The direct causes of maternal death are bleeding $60-70 \%$, postpartum infection $20-30 \%$ and death due to abortion and prolonged labor 10-20\% (Manuaba, 2012).

Infection during the puerperium is the cause of the Maternal Mortality Rate (MMR). Based on the 2012 IDHS, the average maternal mortality rate (MMR) was recorded at 359 per 100,000 live births. The average mortality rate has significantly increased compared to the 2007 IDHS results, which reached 228 per 100,000 (Depkes RI, 2011).

Vitamin A is useful for reducing mortality and morbidity, because vitamin A can increase the body's resistance to infectious diseases such as measles, diarrhea, and ARI (Acute Respiratory Inpection). Vitamin $\mathrm{A}$ is also beneficial for eye health and helps the growth process. Therefore vitamin A is very important for health and survival (Depkes RI, 2011). A study conducted on children aged 6 months whose mothers received vitamin A capsules after delivery showed that there was a decrease in the number of fever cases in these children and a faster recovery time when they had ARI. If children who get enough vitamin A get diarrhea, measles, or other infectious diseases, these diseases do not easily become severe which can endanger the child's life (Kemenkes RI, 2010)

Overcoming the problem of Vitamin A deficiency (VAD) is not only to prevent blindness, but also to promote children's growth and health. According to WHO, child blindness in the world has now reached 1.5 billion with the finding of half a million new cases in one year, this visual disturbance mainly occurs in early life. Vitamin A deficiency in children during this period has a risk and negative impact on the child's survival and can also affect the child's development when the child reaches school age. Since 1992, Indonesia has been declared free of xeropthalmia problems, but $50 \%$ of toddlers still have serum retinol less than $20 \mu \mathrm{g} / \mathrm{dl}$ which will have an impact on the risk of blindness and death due to infection (Naibaho, 2011)

During the puerperium, it is necessary to give vitamin $\mathrm{A}$ to increase the amount of vitamin $\mathrm{A}$ in breast milk. In addition to the mother, vitamin $\mathrm{A}$ is also beneficial for the baby, because during the postpartum period the mother breastfeeds her baby so that the breastfed baby is more immune to disease. The benefits of vitamin $A$ in addition to improving child survival and helping to recover postpartum health are closely related to anemia and reduce the risk of night blindness in nursing mothers (Saleha in Setianingrum, 2014).

Recognizing the importance of vitamin A supplementation, the International Vitamin A Consultative Group (IVACG) at a meeting in Morocco in 2003 recommended that $100 \%$ of postpartum mothers receive high-dose vitamin A capsules (200,000 IU). Vitamin A capsules are given 2 times in a row, namely one red vitamin A capsule immediately after delivery and one capsule the next day at least 24 hours after the first capsule (MOH, 2012).

According to data from the Karimun District Health Office, from 4707 mothers who received vitamin A, 4008 post-partum mothers $(85.1 \%)$. While the highest was Meral Barat subdistrict with $105.8 \%$ and the lowest was Tebing sub-district, 66.0\% (Karimun Health Office Profile, 2017).

In Setianingsih's (2011) study, the low coverage of vitamin A for post-partum mothers was caused by several factors, including the mother's ignorance of the benefits of vitamin A capsules, namely $55.3 \%$ with insufficient knowledge, and $62.3 \%$ lack of postpartum education. The results of statistical tests on the relationship between knowledge level and vitamin A consumption obtained $\mathrm{p}$ value 0.000 education level and vitamin A consumption in postpartum mothers $p$ value 0.033 . Education is an attempt to develop personality and abilities inside and outside of school and lasts a lifetime. Education affects the learning process, the 
higher a person's education, the easier it is for that person to receive information (Notoatmodjo, 2010).

According to Notoatmodjo (2012) in Lawrance Green theory, a health behavior is influenced by driving factors, enabling factors and reinforcing factors. Provision of vitamin A capsules for postpartum mothers as a health behavior is also influenced by these three factors.

From the preliminary survey conducted in the working area of the Tebing Community Health Center, 10 postpartum mothers were given Vitamin A, 3 people knew the benefits of giving Vitamin A to postpartum mothers, 5 people did not know the benefits of giving vitamin A to postpartum mothers, and 2 people still doubt hesitate to consume Vitamin A because they think that Vitamin A can only be consumed by infants and toddlers.

The purpose of this study was to determine the education of postpartum mothers in the Tebing Community Health Center

\section{RESEARCH METHODS}

This study used a descriptive research design. The research was conducted in the working area of the Tebing Community Health Center. In the study, the population was postpartum mothers in the working area of the Tebing Community Health Center. In this study, researchers used purposive sampling technique, which is to determine a sample of the population based on specific objectives or according to the criteria desired by the researcher. The samples taken in this study were postpartum mothers in the working area of the Tebing Community Health Center. The method / technique of data collection was carried out by means of direct communication, namely by asking questions through a written questionnaire with postpartum mothers who were in the working area of the Tebing Community Health Center. Univariate analysis is used to explain or describe the characteristics of each variable under study by presenting a description of the frequency distribution.
RESEARCH RESULT

Table 1. Postpartum Education in the Working Area of the Tebing Community Health Center

\begin{tabular}{cccc}
\hline No & Criteria & Amount & $\mathbf{( \% )}$ \\
\hline 1 & Low & 31 & 70,5 \\
2 & High & 13 & 29,5 \\
\hline \multicolumn{2}{c}{ Total } & $\mathbf{4 4}$ & $\mathbf{1 0 0}$ \\
\hline
\end{tabular}

It can be seen that the majority of respondents' education in the Puskesmas Tebing work area in 2018 is low, namely 31 respondents with a percentage of $70.5 \%$.

\section{DISCUSSION}

It can be seen that the results of research on maternal education in the Puskesmas Tebing work area show that the majority is low, namely 31 respondents with a percentage of $70.5 \%$.

Education is an attempt to develop personality and abilities inside and outside of school and lasts a lifetime. Education affects the learning process, the higher a person's education, the easier it is for that person to receive information (Notoatmodjo, 2010). The higher and more formal a person's education level, the greater the intellectual activity that is carried out and the higher the person's level of knowledge. Sufficient formal education will influence his view of something that comes from outside, education plays an important role in changing knowledge and shaping one's attitudes and behavior. Education is one of the main prerequisites for building a knowledge-based society. In this case it is clear that of the majority of respondents who have a junior high school education, their level of understanding is only limited to knowing and understanding.

This is in line with research conducted by Setianingsih (2011) on the relationship between knowledge, education level and postpartum visits with vitamin A consumption in post-partum mothers in the working area of Puskesmas Rumbia, out of 114 respondents with a low level of education as much as $62.3 \%$. So that the consumption of vitamin $\mathrm{A}$ in postpartum mothers in the working area of the 
Rumbia Health Center is low, namely as many as 32 respondents (45.1\%).

Researchers concluded that education is also one of the factors influencing the provision of vitamin A to postpartum mothers. The higher a person's education level, the greater the intellectual activity that is carried out and the higher the person's level of knowledge. Sufficient formal education will influence his view of something that comes from outside, education plays an important role in changing knowledge and shaping one's attitudes and behavior. Education is one of the main prerequisites for building a knowledge-based society. In this case it is clear that of the majority of respondents with low education, their level of understanding is only limited to knowing and understanding. People who already understand the object or material can explain, mention examples, conclude, predict, and so on to the object being studied, so that they can apply what is obtained by consuming vitamin A. This can be seen from the questionnaire about the educational characteristics of mothers who have education. low as many as 31 respondents (70.5\%).

Sufficient formal education will influence his view of something that comes from outside, education plays an important role in changing knowledge and shaping one's attitudes and behavior. Education is one of the main prerequisites for building a knowledge-based society. In this case it is clear that of the majority of respondents with low education, their level of understanding is limited to knowing and understanding (Notoatmodjo, 2010).

This is in line with research conducted by Setianingsih (2011) on the relationship between knowledge, education level and postpartum visits with vitamin A consumption in postpartum mothers in the working area of Puskesmas Rumbia, out of 114 respondents with a low level of education as much as $62.3 \%$. The results of statistical tests on the relationship between education level and vitamin A consumption in post-partum mothers $\mathrm{p}$ value 0.033 .

The researchers concluded that one of the factors that influenced the provision of Vitamin A to postpartum mothers was education. The level of education will greatly affect a person's level of knowledge, so that it affects his or her mindset because the higher a person's education will have an impact on his increased ability to receive information and apply it will be easier in everyday life.

\section{CONCLUSION}

It is known that the majority of respondents' education is low, as many as 31 respondents (70.5\%) of 44 respondents

\section{Suggestion}

For the community, it is hoped that respondents can add insight and knowledge, especially about vitamin $\mathrm{A}$ in post-partum mothers by attending seminars, counseling and seeking information through print and electronic media so that mothers know, understand and understand. Thus, respondents can apply the information and knowledge they get in real life

\section{BIBLIOGRAPHY}

Almatser, S. (2009). Prinsip Dasar Ilmu Gizi, Jakarta, Gramedia Pustaka Utama

Ambarwati, E.R, Wulandari, D. (2010). Asuhan Kebidanan Nifas, edisi 5, Yogyakarta, Nurul Huda

Arikunto, S. (2010). Prosedur Penelitian Suatu Pendekatan Praktek edisi revisi, Penerbit PT. Rineka Cipta, Jakarta.

BKKBN (2016) Materi Promosi Dan Konseling Kesehatan Reproduksi, Jakarta, Ditkespro BKKBN

Bahiyatun (2009), Buku Ajar Asuhan Kebidanan Nifas Normal, Jakarta, EGC

Departemen Kesehatan Republik Indonesia (2012) Pedoman Pemantauan Wilayah Setempat Kesehatan Ibu Dan Anak, Jakarta

Departemen Kesehatan Republik Indonesia. (2005). Vitamin A, Jakarta, Badan Penelitian dan Pengembangan Kesehatan Pusat Penelitian Kesehatan

Departemen Kesehatan Republik Indonesia. (2005). Vitamin A Penting Untuk Kesehatan Anda, Jakarta

Departemen Kesehatan Republik Indonesia (2009). Panduan Manajemen 
Suplementasi Vitamin A. Jakarta, Depkes RI

Departemen Gizi dan Kesehatan Masyarakat (2011), Gizi dan Kesehatan Masyarakat. Jakarta, Rajawali Pers

Dinas kesehatan Kabupaten Karimun (2017), Profil Dinas Kesehatan, Bidang Kesehatan Masyarakat Dinas Kesehatan Kabupaten Karimun

Kementrian Kesehatan Republik Indonesia (2015) Pedoman Pelayanan Antenatal Terpadu Edisi kedua, Jakarta

Kementrian Kesehatan RI (2016) Buku Kesehatan Ibu dan Anak, Jakarta, Kementrian Kesehatan dan JCIA

Kementrian Kesehatan RI (2017) Modul Pelatihan Keluarga Sehat Jakarta, Kementrian Kesehatan

Mahfoedz (2008). Metodologi Penelitian Bidang Kesehatan, keperawatan, Kebidanan, Kedokteran, Jakarta

Notoadmojo, Soekidjo (2003) Pendidikan dan Perilaku Kesehatan, Jakarta, Penerbit Rineka Cipta

Notoadmojo, Soekidjo (2012) Pendidikan dan Perilaku Kesehatan, Jakarta, Penerbit Rineka Cipta

Nugroho, dkk (2014), Buku Ajar Asuhan Kebidanan Nifas, Jakarta, Penerbit Nuha Medika

Setianingsih (2011), Hubungan pengetahuan, tingkat pendidikan dan kunjungan nifas dengan konsumsi vitamin A pada ibu nifas di wilayah kerja Puskesmas Rumbia Tahun 2011, http://poltekkes-tjk.ac.id/ diunduh tanggal 19 Februari 2018

Sulistyaningsih (2012), Sikap Manusia Teori dan Pengukurannya, Yogyakarta, Pustaka Pelajar

Sulistyawati, (2012), Buku Ajar Asuhan Kebidanan Pada Ibu Nifas, Yogyakarta: Andi Offset Ummi Khasanah Bantul/ https://digilib.uns.ac.id/ diunduh tanggal 3 maret 2018 